\title{
Meat productivity of young horses in the conditions of year-round grazing
}

\author{
Olga Yankina ${ }^{1, *}$, Anna Prihodko ${ }^{1}$, Natalia $\mathrm{Kim}^{1}, \quad$ Natalia Chugaeva ${ }^{1}$, and \\ Igor Nikolaevskiy ${ }^{1}$ \\ ${ }^{1}$ Primorskaya State Academy of Agriculture, 692510, Ussuriysk, pr. Blyukhera, 44, Russia
}

\begin{abstract}
Meat herd horse breeding is one of the most promising projects in the industry, especially in peasant (farming) households. Meat herd horse breeding is one of the most promising areas in the industry, especially in peasant (farm) households. The number of meat herd horses is 438.2 thousand heads, incl. in agricultural organizations 161.2 thousand heads (36.8\%), in peasant farms and individual entrepreneurs - 277 thousand heads (63.2\%). In the conditions of the Primorsky Territory, horse breeding is not the main branch of animal husbandry, nevertheless, there are enough territories here where horse breeding could develop successfully. Breeds such as the Vladimir and Soviet heavy draft do not require much human participation, and they themselves get their own food. At the same time, the main method of keeping and breeding these breeds is herd. The assessment of meat productivity of crossbred young horses with stallions of Sovetskaya and Vladimirskaya heavy draft breeds was carried out. The use of stallions of the Sovetskaya heavy draft breed in horse breeding allowed increasing the slaughter yield by $3.6 \%$ and improve the morphological composition of the carcass in comparison with the Vladimirskaya heavy draft breed.
\end{abstract}

\section{Introduction}

Nowadays, horse meat is consumed by the population of France, Belgium, Holland, Sweden, Norway, Finland, Switzerland, Hungary, Czech Republic, Slovakia, Turkey, Denmark, Italy, Japan, Kazakhstan, Kyrgyzstan, Uzbekistan and other countries. In Russia, horse meat has long been important in the nutrition of the population of Bashkiria, Tatarstan, Yakutia, Buryatia, Gorny Altai, Tuva and a number of regions of the North Caucasus, where horse breeding is carried out by the herd method and does not require large costs [3].

Horse meat is valued primarily for the presence of complete proteins, B vitamins, especially niacin, in it. It contains a large amount of iron and important trace elements: cobalt, iodine, copper. By most indicators, horse meat is considered equivalent to beef, but horse meat has a significant advantage in the content of important amino acids and microelements, especially lipotropic substances. In particular, the essential amino acid histidine is found in horse meat proteins in large quantities (6.0-9.7\%) compared to beef

\footnotetext{
*Corresponding author: olgayanleon@rambler.ru
} 
(3.2-4.1\%). In addition, horse meat contains a significant amount of vitamin A (up to 20 $\mathrm{mg} \%$ in fat), thiamine $(0.07 \%)$, riboflavin $(0.1 \mathrm{mg} \%)$ and nicotinamide $(4.2 \mathrm{mg} \%)$.

Table 1 shows the composition and energy value of horse meat in comparison with the meat of other farm animals [6].

The production of fatty horse meat has been particularly relevant in recent years. The dietary nutritional benefits of horse meat largely depend on the biological value of the fat it contains: it is easy-melt, has a beneficial effect on human metabolism and prevents the development of atherosclerosis and other diseases. The fat of young horses contains more essential fatty acids and has a higher biological value than the fat of older horses. The melting point of horse fat varies in the range of $27.6-28.3^{\circ} \mathrm{C}$ depending on the age of the horse. The cholesterol content in horse fats depends on their anatomical and topographic location: in the subcutaneous inguinal fat $-31.9 \%$; in the subcutaneous fat of the sacrum $25 \mathrm{mg} \%$; fatty crest of the neck - $10.4 \mathrm{mg} \%$; perirenal - $18.7 \mathrm{mg} \%$; abdominal fat - 22.9 $\mathrm{mg} \%$; mesenteric $-12.5 \mathrm{mg} \%$. In the fats of other types of farm animals, the cholesterol content is: in lamb - $29 \mathrm{mg} \%$, in beef - $75 \mathrm{mg} \%$, in pork - 74-126 mg\%. [4].

Table 1. Composition and energy value of meat of farm animals.

\begin{tabular}{|c|c|c|c|c|c|}
\hline $\begin{array}{c}\text { Type of } \\
\text { meat }\end{array}$ & Water, \% & Protein, \% & Fats, \% & Minerals, \% & $\begin{array}{c}\text { Calories, } \\
\text { cal/100 g }\end{array}$ \\
\hline $\begin{array}{c}\text { Horse } \\
\text { meat }\end{array}$ & 71.0 & 22.6 & 5.5 & 0.9 & 136.4 \\
\hline Beef & 68.3 & 20.0 & 10.7 & 11.1 & 181.5 \\
\hline Veal & 68.0 & 20.0 & 11.0 & 1.0 & 184.3 \\
\hline Pork & 65.1 & 19.0 & 15.0 & 0.9 & 217.4 \\
\hline Lamb & 72.0 & 21.0 & 6.1 & 0.9 & 142.8 \\
\hline Mutton & 34.8 & 17.0 & 17.2 & 1.0 & 229.6 \\
\hline
\end{tabular}

Horse fat is essential in cleansing the body of toxins, since it contains a large amount of polyunsaturated fatty acids (arachidonic, linoleic, linolenic) with free valences. Horse fat obtained from horses raised on pasture is widely used in cosmetology as a valuable ingredient in the production of creams for women and men and other accessories in such countries as China, France and others [5].

The properties of horse meat make it possible to use it in the production of children's meat products. Horse meat has dietary and hypoallergenic properties due to the lack of antigenic affinity for cow's milk and beef proteins, the most common allergens. The high therapeutic efficacy of horse meat in case of food allergies, anemia, various forms of intestinal malabsorption, celiac disease, lactase deficiency has been confirmed by numerous clinical tests. In addition, horse meat is the safest in terms of health due to the immunity of horses to parasitic diseases, as well as spongiform encephalopathy. [1].

\section{Materials and Methods}


In the Primorsky Territory, productive meat horse breeding has great prospects for development, which has been proven by one of the largest local enterprises - IE "Konstantin". The farm has about 600 head of brood stock - crossbreds with heavy-duty breeds, well adapted to the conditions of year-round grazing. To improve the meat qualities of horses in the farm, stallions of heavy draft breeds are used: sovetskaya and vladimirskaya.

In this regard, we set a goal - to assess the meat productivity of young horses in the conditions of a year-round grazing.

The studies were carried out in the conditions of the IE "Konstantin" of the Primorsky Territory. For this, using the method of analogs, two groups of stallions of 10 heads each were formed. In the first group, there were foals (stallions) - crosses obtained by crossing local mares with a stallion of thesovetskaya heavy-draft breed, in the second - with a stallion of the vladimirskaya heavy-draft breed. To study meat productivity, a control slaughter of three heads of stallions from each group was carried out when removed from feeding at the age of 24 months. Meat productivity was studied according to the following indicators:

- pre-slaughter live weight - the weight of the animal after 24 hours of starvation,

- slaughter mass - a mass of bloodless carcass together with internal fat, but without the head, skin, tail, internal organs, with the limbs cut off at the hock and wrist joints.

- slaughter yield - the ratio of the slaughter weight to the pre-slaughter weight, expressed as a percentage;

- morphological composition of the carcass - the percentage of the mass of pulp, bone tissue, fat tissue to the mass of the carcass.

The digital material was processed by the biometric method according to I.A. Kalashnikov.

\section{Results}

The meat productivity of young horses after slaughter is characterized by indicators of slaughter yield and morphological composition of the carcass. Table 2 shows the postslaughter indicators of meat productivity of crossbred young horses.

Table 2. Indicators of control slaughter of crossbred young animals at 24 months.

\begin{tabular}{|c|c|c|}
\hline Indicator & $1^{\text {st }}$ test group & $2^{\text {nd }}$ test group \\
\hline Pre-slaughter weight, kg & $603.0 \pm 37.5$ & $510.1 \pm 32.5$ \\
\hline $\begin{array}{c}\text { Slaughter weight (carcass } \\
\text { weight + internal fat), kg }\end{array}$ & $338.3 \pm 8.56$ & $267.8 \pm 6.55^{* *}$ \\
\hline Slaughter yield, $\%$ & $56.1 \pm 0.3$ & $52.5 \pm 0.4^{* *}$ \\
\hline$* * \mathrm{P} \leq 0.01$ & &
\end{tabular}

The results of the control slaughter showed that the crossbred young animals of the 1st test group are characterized by the best slaughter qualities. They significantly exceeded their peers from the 2 nd test group by $70.5 \mathrm{~kg}$ in slaughter weight, and $3.6 \%$ in slaughter yield. 
We carried out studies of the morphological composition of the carcasses of crossbred young animals, which made it possible to determine the yield of pulp, bones and their ratio (Table 3).

Table 3. Morphological composition of carcasses of crossbred young animals.

\begin{tabular}{|c|c|c|c|c|}
\hline \multirow{2}{*}{ Indicator } & \multicolumn{2}{|c|}{$1^{\text {st }}$ test group } & \multicolumn{2}{c|}{$2^{\text {nd }}$ test group } \\
\cline { 2 - 5 } & $\mathrm{kg}$ & $\%$ & $\mathrm{~kg}$ & $\%$ \\
\hline Carcass weight, $\mathrm{kg}$ & 338.3 & 100 & 267.8 & 100 \\
\hline Pulp weight, $\mathrm{kg}$ & 285.2 & 84.3 & 224.4 & 83.8 \\
\hline Fat tissue mass, $\mathrm{kg}$ & 7.4 & 2.2 & 5.1 & 1.9 \\
\hline Bone mass, $\mathrm{kg}$ & 45.7 & 13.5 & 37.5 & 14.3 \\
\hline Meat index, units & 6.2 & - & 6.0 & - \\
\hline
\end{tabular}

The results of the study showed that the crossbreed young animals of the 1st test group were significantly superior in all parameters to the young animals of the 2 nd test group: carcass weight - by $70.5 \mathrm{~kg}$, pulp weight - by $60.8 \mathrm{~kg}$, fat weight -by $2.3 \mathrm{~kg}$, bone tissue weight - by $8.2 \mathrm{~kg}$. At the same time, the meat content coefficient turned out to be 0.2 units higher.

\section{Discussion}

The use of stallions of heavy draft breeds as improvers improves the meat productivity of horses. At the same time, breeders recommend Russian, Soviet, Lithuanian and Vladimir heavy trucks for interbreeding. The farm uses stallions-producers of two heavy draft breeds - Vladimir and Soviet. Both breeds are considered excellent improvers for local broodstock. The average live weight of Soviet stallions is $781 \mathrm{~kg}$, mares $-654 \mathrm{~kg}$. The largest animals weigh up to $1000 \mathrm{~kg}$. Soviet heavy draft breed -65 years old . [8].

The main feature of the Vladimir breed is the large size of individuals. Their average weight is $900 \mathrm{~kg}$, but most often - 1-1.2 tons [9]. Crossbred foals obtained from heavy draft breeds showed excellent meat productivity, but also had some peculiarities. The best meat productivity was shown by crosses from a Soviet heavy truck, which confirms the physiological early maturity of foals, since by the mass of adult animals, Vladimir heavy trucks are larger. As noted by Yu.Yu. Kolomeets. (2013), due to hereditary characteristics, as well as differences in the conditions of existence, the maximum development in different animal species occurs at different ages. Therefore, it is important to note the early maturity of animals, that is, the ability to ripen quickly.

Therefore, it is important to note the early maturity of animals, that is, the ability to ripen quickly. When using animals for meat, when it is economically viable to obtain a complete carcass at a younger age, the growth rate of the animals and their ability to deposit fat are critical [2]. 


\section{Conclusions}

Thus, the data obtained show that the meat productivity of young animals obtained from the Soviet heavy draft breed during the feeding period of 24 months significantly exceeds the young animals obtained from the vladimirskaya heavy draft breed in terms of pre-slaughter and slaughter weight, slaughter yield, and is also characterized by the best morphological composition of the carcass.

\section{References}

1. A.V. Ustinova, O. K. Derevitskaya, M.A. Aslanova, N.E. Belyakina., Timoshenko N.V., M.A. Kretov Functional products for children based on meat, Food industry, 3, 14-15 (2005)

2. Yu.Yu. Kolomeets, A.D. Volkov Herd horse breeding of Khakassia, Grew up. acad. s.kh. sciences. Sib. region. separation. State scientific. uchr. Nauch.-issled. Institute of Agrarian. problems of Khakassia, 168 (2013)

3. I.A. Kalashnikov, V.A. Mikhailova Statistical methods of data processing, I; FSEI HPE “Buryat State Agricultural Academy named after V.R. Filippov”, 48 (2007)

4. S.A. Kozlov, V.A. Parfenov Horse breeding, 352 (2012)

5. A.B. Latypov, R. Ya. Safikhanov Obtaining ecologically safe horse breeding products on the basis of a comprehensive study of the content of heavy metals in the soil cover of Bashkortostan, Samara Scientific Bulletin, 2 (11).- p. 106-111 (2015)

6. M.Zh. Nurushev The role of horse breeding in the production of environmentally friendly products, Vestnik of the Orenburg State University, 141-144 (2005)

7. Silvius Stanciu. Horse Meat Consumption - Between Scandal and Reality, Procedia Economics and Finance, 23, 697 - 703 ( 2015 )

8. Soviet heavy draft breed - 65 years old, All-Russian Research Institute of Horse Breeding

9. Vladimir heavy truck: characteristics of horses, maintenance and care, all about our pets 